\title{
Consumer Preferences for Water Supply at Njala University, Njala Campus in Southern Sierra Leone
}

\author{
Abubakarr S. Mansaray', John P. Kaissam¹, Alfred S. Bockarie'2, Hawanatu Sam² \\ ${ }^{1}$ Chemistry Department, Njala University, Njala, Sierra Leone \\ ${ }^{2}$ Institute of Environmental Management and Quality Control (IEMQC), Njala University, Njala, Sierra Leone \\ Email: absmansaray@gmail.com
}

Received 14 February 2016; accepted 18 March 2016; published 21 March 2016

Copyright (C) 2016 by authors and Scientific Research Publishing Inc.

This work is licensed under the Creative Commons Attribution International License (CC BY). http://creativecommons.org/licenses/by/4.0/

(c) (i) Open Access

\section{Abstract}

Suppliers of potable water would benefit from a sustainable business as long as consumers continue to prefer their brand. Some of the reasons for choosing a particular brand include water quality, cost of the finished product, reliability of supply, and supplier ethics. These important determinant factors form the basis of this work. The objective is to delineate consumer preferences for water supplied to the Njala campus community, in southern Sierra Leone, and the underlying determinant factors. A list of questions administered to 140 respondents, are used to help achieve the objective. The results of water quality tests are also used to determine if quality has anything to do with consumer preference. The Oxfam Delagua water testing kit is customized to incubate and enhance counting of fecal and no-fecal coliform bacteria in water samples. Bacterial contamination is the major concern in the study area. The survey results reveal the consumers prefer package water for drinking. Treated water from Tia River is only used for other domestic purposes. The consumers do not trust the quality of water supplied from Tia River, albeit filtration and disinfection at the University's treatment center. This distrust is confirmed by the bacterial test. None of the campus water sources meet recommended guidelines for drinking water. The consumers are, however, willing to shift preference from package to tap drinking water if treatment comes with quality assurance. The university could benefit through economic gratification, customer protection, and reduced plastic waste from package drinking water.

\section{Keywords}

Consumer, Preference, Water Supply, Water Quality, Community, Business Model 


\section{Introduction}

Sierra Leone, as a nation, has limited amount of data that could be used to establish relationships between available water sources and consumer preferences. However, these types of data would inform planning for sustainable water supply to communities in the nation.

In the study area, it is widely believed there is abundant water available for consumption, especially in the rainy season. Rainwater recharges the Tia River, streams, ponds, and wells. Citizens have access to fresh water from all these sources, in addition to rainwater. Consumers are, however, not clear about the quality of available fresh water. This uncertainty has led to the demand for water from different sources, depending on the use category. However, limited data in the past has diminished the possibility of explaining preferences for the different sources per use category. The objective of this study, therefore, is to delineate consumer preferences and their underlying determinant factors for water supply at the Njala University, Njala campus, in southern Sierra Leone.

Water quality, cost, and reliability in supply are the key determinant factors for consumer behavior [1]. In order to enhance positive consumer behavior, the supply source must not compromise the health of the community; it must be accessible; it must be available in quantities sufficient for the intended use [2]. In a 2014 study in Cambodia, the authors report in their paper that the burden of arsenic removal makes public water supply expensive for consumers. According to the study results, consumer shift to alternative supply sources, such as rain harvesting and protected hand dug wells, eases the burden of affordability [3].

Consumer preference is important to sustainable community water supply. Marketing strategies should be able to meet consumer satisfaction, minimize health risks, scope demographic variables, address organoleptic concerns (using the sense organs, especially taste, to perceive water quality), and ensure healthy ethical relationship with consumers [4]. Saylor and colleagues [5] explored the demographic variables in drinking water preferences at Purdue University. Their study results revealed that women drank disproportionately more bottled water than men, while undergraduate students drank more bottled water than graduate students and faculty. The major influencing factor for this variability, according to the paper, is the lack of trust in the quality of tap water. In developing countries, consumers' preference for package drinking water (bottled and sachet water) has become significant. This is attributed mainly to the inability of tap water suppliers to catch up with increasing populations and quality requirements [6] [7].

\section{Materials and Methods}

\subsection{Description of Study Area}

Njala campus is located in Kori Chiefdom, Moyamba District, at Latitude $8^{\circ} 07^{\prime}$ North and Longitude $12^{\circ} 05^{\prime}$ West (Figure 1). The campus receives an approximate total of 2875 gallons of water per day from various supply sources.

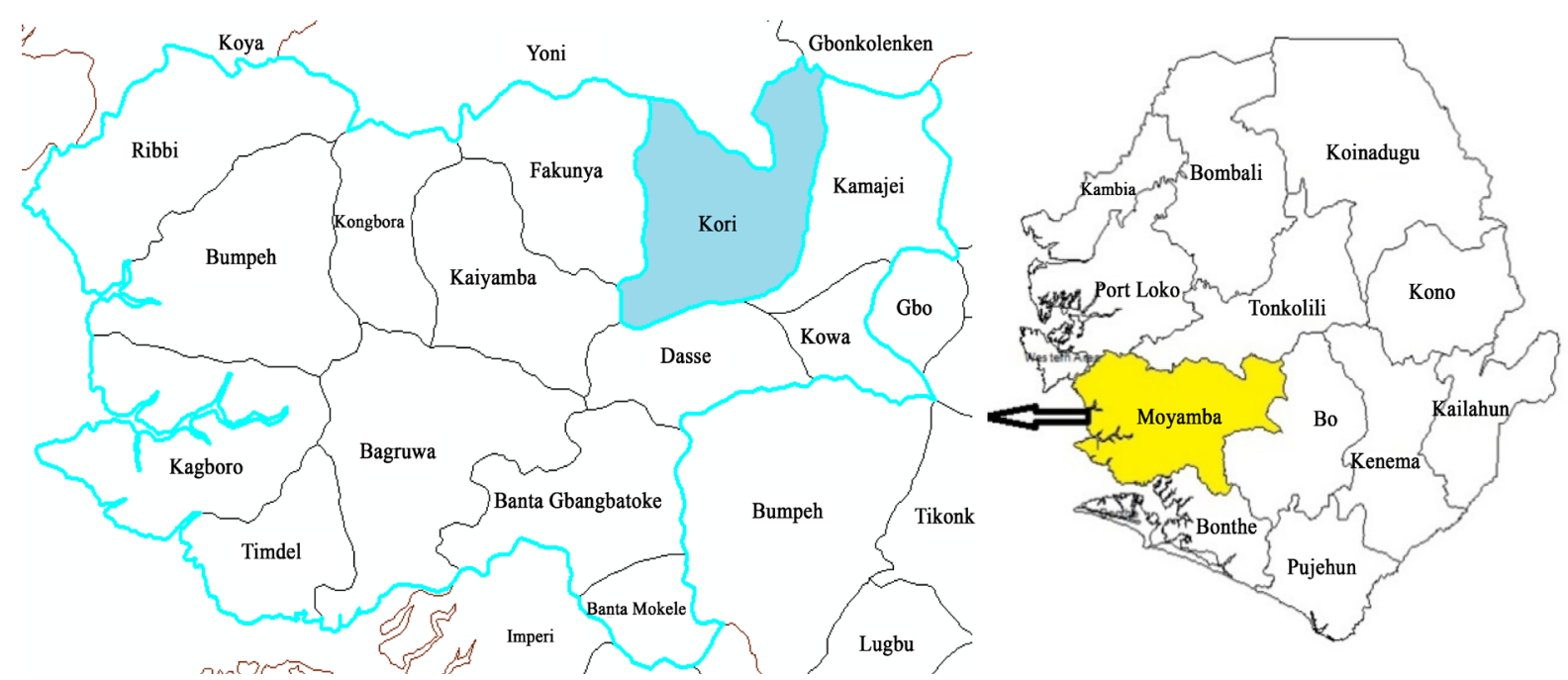

Figure 1. Map of Sierra Leone showing Moyamba district (highlighted yellow) and Kori chiefdom (highlighted blue). 


\subsubsection{Njala University Water Works}

The raw water pump draws water from the intake point at Tia River and pumps to the treatment center, 200 meters away, through a 6-inch diameter pipe. At the treatment center the water passes through slow sand filters at a flow rate of 1.74 gallons per minute (GPM). The filters are made up of graded layers of filtration material: gravel at the bottom, coarse sand in the middle, and fine sand at the top. There is no backwash mechanism; workers manually remove dirt from the top layer when the flow rate becomes too low or there is increased turbidity.

The filtered water flows through a 4-inch diameter pipe into a disinfection tank where chlorine is manually added. The chlorine is diluted into arbitrarily determined concentrations, and added to the filtered water. The treated water is stored in a 5000-gallon finish water tank to wait for distribution by gravity flow to staff quarters, administrative buildings, and student hostels. The treated water is supplied to campus 5 times a day $(25,000$ gallons/day).

\subsubsection{Water Bowsers}

The University's water bowsers fetch water from neighboring streams to fill 1000 -gallon tanks at staff and student quarters. However, supply from this source is erratic and is done as needed. Additionally, there is no treatment of water from this source.

\subsubsection{Package Drinking Water}

Bottled and sachet water are the two main drinking water sources on campus. There are many brands of package drinking water produced in the country. Most of the brands use imported filters and UV disinfection before packaging. The source of water varies from brand to brand; typical sources include tap water, wells, rainwater, streams, and rivers. Residents on Njala campus have random preference for the different brands; it largely depends on which brand is available during the time of purchase. According to the survey results, an estimated total of 267 gallons per day of package drinking water is consumed on campus. Sachet water is the primary type of package drinking water, supplied in bundles of twenty 500 milliliter $(\mathrm{mL})$ sachets.

\subsubsection{Hand Dug Wells}

Njala campus has two hand-dug water wells. The well at the back of Florence Carew flats is an open well available to students for use. A second well located in front of Quadrangle flats has been named by students as "Jacky body". This well has a hand pump and is used for drinking by majority of students on campus. It provides an estimated total of 108 gallons of drinking water per day. Figure 2 is a map showing the water sources on Njala Campus.

\subsection{Sampling}

Questionnaires were administered to help determine consumer preferences for water supply on campus. Njala campus was divided into 14 zones and 10 questionnaires administered per zone, Table 1 shows the zones and their approximate populations.

\subsection{Microbiological Parameters}

Water samples from each supply source were tested for presence/absence of harmful microorganisms. The Oxfam Delagua water testing kit was used for bacteriological examination. The kit has petri-dishes, absorbent pads, membrane filters, hand operated vacuum pump, and grease. The equipment and all its accessories are sterilized before use, in order to prevent inaccurate results due to contamination. $50 \mathrm{~mL}$ of each water sample is measured using a standard sterilized measuring cylinder. The water sample is pumped through a membrane filter of pore size 0.45 microns. The membrane filter is incubated for $18-22$ hours at $44^{\circ} \mathrm{C}$ in suitable colonies of characteristic shape and color. Yellow Colonies are formed for fecal coliform bacteria. All other colors are classed as non-fecal coliform bacteria. The bacteria are counted per $100 \mathrm{ml}$ of water sample as follows: [Number of colony forming unit/Volume of water sample filtered $(50 \mathrm{ml}).] * 100$.

\section{Results and Discussions}

\subsection{Source of Water}

Table 2 presents the water sources that the consumers preferred for various purposes; 100 participants $(71.4 \%)$ 


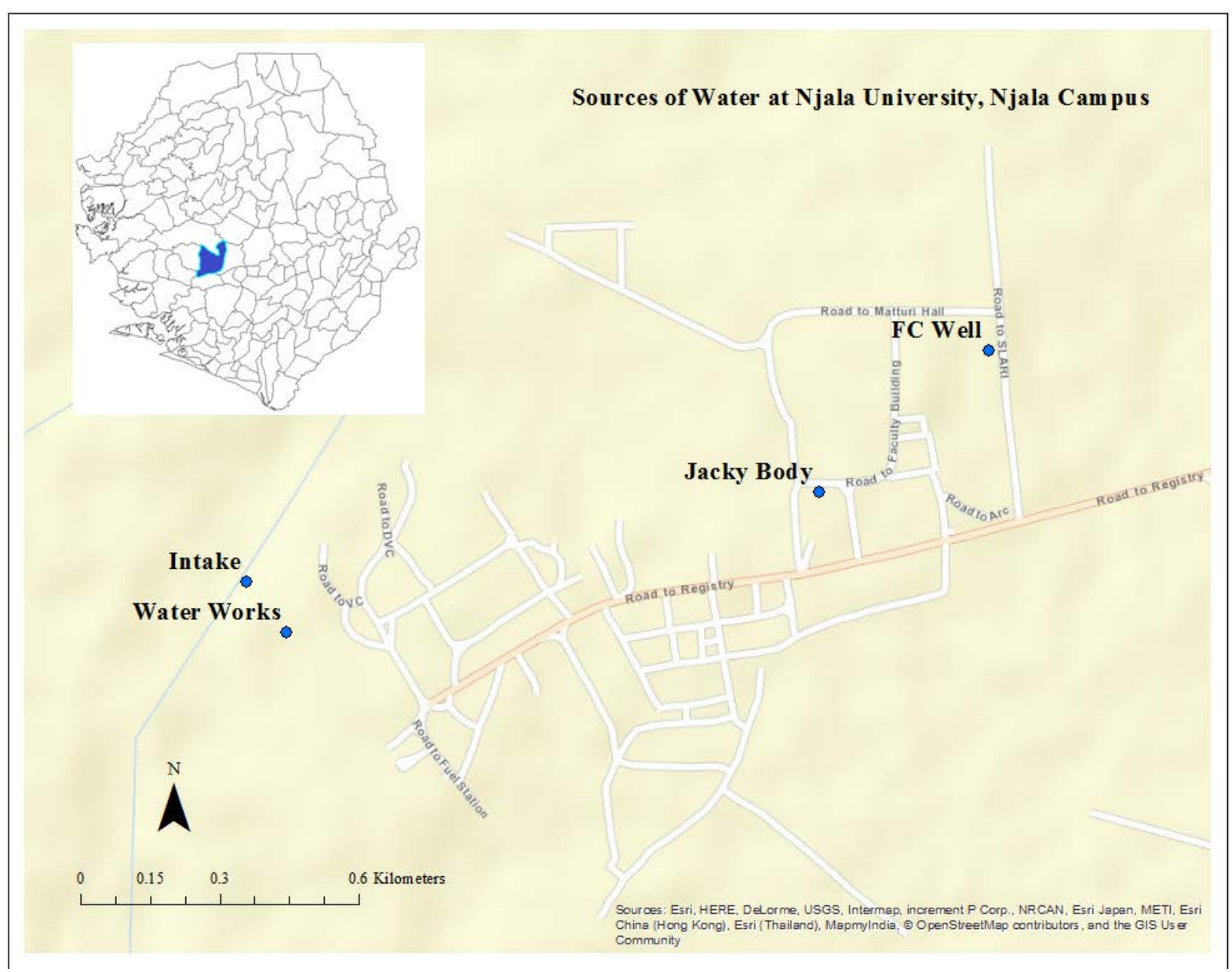

Figure 2. Source of water supply at Njala University, Njala campus.

Table 1. Data collection zones and their approximate populations.

\begin{tabular}{ccc}
\hline Zone & Name of Neighborhood & Approximate Population \\
\hline 1 & Crown Agent Quarters (CA) & 170 \\
2 & SLARI Quarters 1 \& 2 & 109 \\
3 & Winters (SH) & 76 \\
4 & Quadrangle (SH) & 110 \\
5 & Tourist (SH) & 30 \\
6 & Estate Quarters (EQ) & 70 \\
7 & Senior Staff Quarters (SSQ) & 252 \\
8 & Junior Staff Quarters 1 \& 2 (JSQ) & 492 \\
9 & Lungi Quarters (LQ) & 111 \\
10 & Agric. Quarters (AQ) & 40 \\
11 & Torkpombu (TK) (SH) & 198 \\
12 & Secretariat Quarters (SQ) & 27 \\
13 & Matturi (SH) & 640 \\
14 & Florence Carew (FC) 1, 2, 3 (SH) & 140 \\
& Total & $\mathbf{2 4 6 5}$ \\
\hline
\end{tabular}

${ }^{1}$ SH: Student Hostel. 
Table 2. Preference by source.

\begin{tabular}{ccccc}
\hline \multirow{2}{*}{ Use Category } & \multicolumn{4}{c}{ Source } \\
\cline { 2 - 5 } & Hand Pump & Sachet Water & Bottled Water & Tap \\
\hline Drinking & 42 & 44 & 14 & 0 \\
Cooking & 5 & 0 & 0 & 95 \\
Laundry & 3 & 0 & 0 & 97 \\
Bathing & 4 & 0 & 0 & 96 \\
Ablution & 9 & 2 & 0 & 79 \\
Cleaning & 3 & 0 & 0 & 97 \\
Dishwashing & 2 & 0 & 0 & 98 \\
\hline
\end{tabular}

took part in the survey. Nobody drinks from the University's supplied tap water. The respondents do not trust the quality of water coming from this tap. They prefer bottled and sachet water, supplied from outside sources. The students mostly depend on the Jacky Body well for drinking. Most of the student respondents said they could not afford to buy package drinking water and they trust the quality of water coming from the well.

The consumers, however, use the tap water for all other domestic purposes. Unfortunately, these purposes can serve as sources of exposure to the perceived contaminated water [8]. If the water is indeed contaminated, the consumers may be prone to resulting health problems. This led to the need for verification of the quality of water supplied to campus.

Based on the responses, the major determinant factor for source preference is quality. The consumers would depend entirely on the University's supplied tap water if the quality is ensured and guaranteed. They indicated that they face financial and logistical burdens of sourcing drinking water from other suppliers. A bundle of sachet water from credible suppliers is about $\$ 1.50$ (USD), bottled water costs 3 times more, and transportation makes it even more costly. Table 2 shows consumer preferences for different water sources based on use category.

\subsection{Water Quality at Njala Campus}

The consumers lack trust in the quality of water treated and supplied from the Tia River; this gave rise to the need for a confirmatory water quality test. Samples were analyzed for coliform bacteria, in both the rainy and dry seasons. Based on the types of land use practice in the area, the major quality concerns for Tia River are physical (sediment load) biological contamination (open defecation). There is no industrial activity in the area. Additionally, the presence of coliform bacteria, indicating the presence of harmful microorganisms in water, would help in determining if the water sources are potable [9]. The two seasons were covered in order to characterize the sources of any contamination resulting from seasonality [10]. Table 3 presents fecal and non-fecal coliform bacteria counts in $100-\mathrm{mL}$ of samples selected from the sources as listed.

With the exception of package water, all the other samples did not meet the World Health Organization (WHO) recommended guideline of zero counts per sample of fecal coliform bacteria, and 10 counts per sample of non-fecal coliform bacteria. The samples were contaminated with harmful microorganisms, some of them too numerous to count (TNTC), even after treatment of the water. These results justify consumer concerns for the quality of water supplied to Njala campus.

Harmful microorganisms increase in population in the wells during the rainy season. These might be contributed through shallow groundwater flow in the area; similar conclusion was drawn in a 2015 study in other parts of Sierra Leone [11].

The high microbial counts in the river during the rainy season could be attributed to open defecation, and the human and animal waste, ending into the river through surface runoff or direct dumping into the upstream river [12]. The reduced bacterial counts in the dry season are probably due minimal surface runoff.

Assuming TNTC is equivalent to 200 microbial counts in $100-\mathrm{mL}$ sample, the Water Works facility has minimum treatment (disinfection) efficiency of $81 \%$ and a maximum of $96 \%$. However, the finish water still needs further disinfection due to fecal coliform counts being greater than the WHO recommended limit.

Microbial counts in the treated water increase along with the pipeline. This may be due to recontamination, through leaks in the pipes, in areas where human activities may be introducing harmful microorganisms into the 
Table 3. Coliform bacteria in water samples.

\begin{tabular}{ccccc}
\hline Sample Location & \multicolumn{2}{c}{ Fecal Coliform Bacteria } & \multicolumn{2}{c}{ Non-Fecal Coliform Bacteria } \\
\cline { 2 - 5 } March 2015 & June 2015 & March 2015 & June 2015 \\
\hline Grafton Spring Water (Bottle and Sachet) & 0 & 0 & 0 & 0 \\
Water Bowser & TNTC & TNTC & TNTC & TNTC \\
Jacky Body & 2 & 48 & 4 & 88 \\
Florence Carew Well & 23 & 72 & 12 & TNTC \\
Tia River Intake Point & 82 & TNTC & 6 & 12 \\
Water Works (Treated Water) & 3 & 20 & 14 & 14 \\
Senior Staff Quarters & 18 & 21 & 8 & 56 \\
Staff Common Room & 4 & 76 & 20 & 50 \\
Estate Quarters & 2 & 36 & 34 & 22 \\
Lungi Quarters & 2 & 66 & 20 & 91 \\
Winters SH & 18 & 96 & 3 & 16 \\
Florence Carew SH & 22 & TNTC & 12 & 77 \\
Matturi SH & 4 & 85 & 6 & 45 \\
\hline
\end{tabular}

${ }^{1}$ TNTC: Too Numerous to Count.

water. It may also be due to dwindling residual disinfection along the pipeline [8], a probable boost to aerobic microbial metabolism in the water. However, this possibility requires further clarification as to the presence of organic carbon and oxygen or other aerobic terminal electron acceptors [13].

Clearly though, residual disinfection does not satisfy chlorine demand in the University's treated water. The manual addition of chlorine does not take into account when is disinfection too high or too little. There seem to be no contact time management at the finish water tank; contact time allows for complete dispersal of chlorine to enhance contact with and subsequent destruction of microorganisms. The possible existence of dead zones in the finish water tank might also be playing a role in the ineffective chlorine disinfection [14].

Consequently, the current treatment system is incapable of bringing the campus water to safety standards. Further optimization of the system is required to enhance international best practice for drinking water treatment works.

\subsection{Willingness to Pay for Treated Water}

The consumers are willing to pay for campus water if treatment is upgraded to safety standards. It is revealed in Figure 3 that the primary reason for preferring sachet and bottle water is drinking. Majority of the respondents will pay for treated water from tap and the wells. Consumers are even willing to pay for rainwater as long as it is properly treated. However, majority $(87 \%)$ do not agree to pay for rainwater.

The University has the opportunity to take advantage of this willingness to pay on the part of consumers. An improvement in the quality and reliability of water supply on campus will benefit the environment as to reduction in plastic waste from water bottles and sachets. Additionally, the University will benefit economically from tariffs charged to the consumers. The improved supply system will also ease burden on students, staff, and members of the community with regard to transportation requirements for purchasing package water from outside sources.

Campus authorities could either improve on the current informal marketing model, or develop either or both of organic growth and proposal models. The choice could be based on determinant parameters such as feasibility, cost implications, socioeconomic status, and sustainability.

The informal model is the current marketing strategy in the campus community. There is no organized system of demand and supply of potable water. The source, quality, and quantity of supply are erratic as they are subject to unpredictable market forces. The campus authorities could develop or strengthen policies that ensure regularization of suppliers with the objective of promoting and protecting consumer satisfaction. 


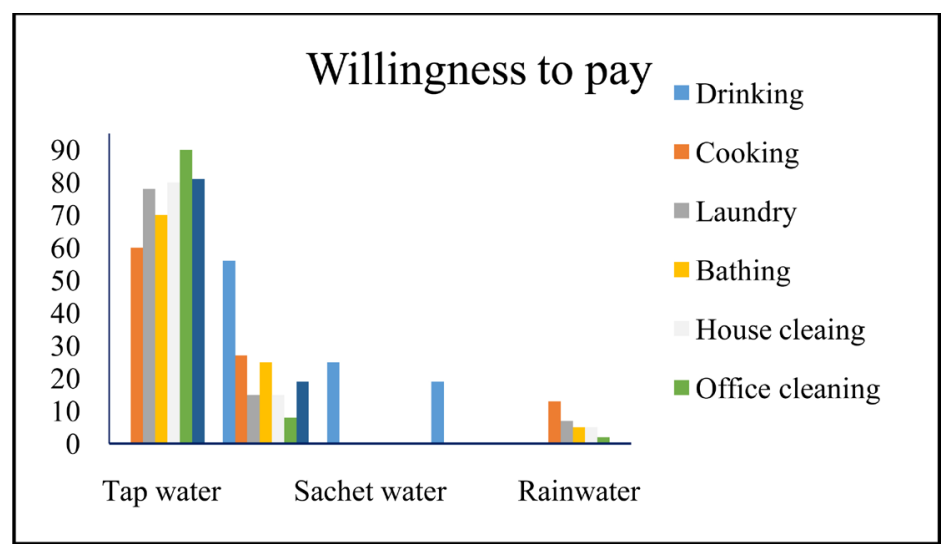

Figure 3. Willingness to pay for treatment and supply of water.

The organic growth model [15] will be based on a public-private partnership wherein the administration or an allied department at Njala campus would lease to own a water treatment plant from a private company. A payment plan is agreed upon and accomplished through some form of scheduled payment by staff and students residing at Njala campus and neighborhoods. This has the potential of guaranteeing quality control, quality assurance, economic gratification, and protection of consumer health.

In the proposal strategy, the University administration solicits funding from donors/philanthropists to purchase a water treatment facility, recruit and train operators to run it. The treated water is supplied to the campus community as a fringe benefit. Alternatively, and as a sustainability strategy, consumers will be charged a minimal tariff to use in operation and maintenance of the equipment.

\section{Conclusions}

This work presents consumer preferences for water sources at Njala University, Njala campus, in southern Serra Leone. Part of the objective is to delineate the determinant factor(s) for such preferences. No prior data exist to establish a relationship between what the consumers prefer and what can lead to such preference. Customer satisfaction, however, is a key element in a sustainable water supply business.

The sources of water supplied to the study area include tap water with source at Tia River, bottled and sachet drinking water with sources from different parts of the country, rainwater and well water. Package (bottled and sachet) water is used mainly for drinking; the tap water is used for all other domestic purposes: cooking, bathing, cleaning and laundry inclusive.

According to the study results, consumers refuse to drink from the tap mainly for health reasons. Nobody trusts the quality of water supplied through the tap. The university has not employed state of the art equipment as well as trained and qualified staff to ensure effective and efficient treatment of water at all times.

With water quality as the main determinant factor for consumer preference, a confirmatory water quality test was carried out to ascertain the authenticity of such concern. Since the study area is mainly susceptible to biological contamination of water bodies, the test involved fecal coliform bacteria counts in sampled water from various locations.

The results reveal that water supplied from all sources, other than bottled and sachet drinking water, is not good for human consumption. Coliform bacteria counts did not meet WHO recommended guidelines for drinking water. This legitimizes the consumers' concern for the quality of water supplied on campus.

The respondents indicate willingness to pay if water from the Tia River or the wells is treated to meet recommended standards. They already pay for bottled and sachet drinking water, the quality of which is only based on perceptions. Improving treatment on campus will help mitigate accumulation of plastic waste from bottles and sachets, ease the burden of travel to buy package water and generate income for the university.

\section{References}

[1] Graymorea, M.L.M. and Wallisa, A.M. (2010) Water Savings or Water Efficiency? Water-Use Attitudes and Behaviour in Rural and Regional Areas. International Journal of Sustainable Development \& World Ecology, 17, 84-93. 
http://dx.doi.org/10.1080/13504500903497249

[2] Jagals, P. (2006) Does Improved Access to Water Supply by Rural Households Enhance the Concept of Safe Water at the Point of Use? A Case Study from Deep Rural South Africa. Water Science \& Technology, 54, 9-16. http://dx.doi.org/10.2166/wst.2006.441

[3] Chamberlain, J.F. and Sabatini, D.A. (2014) Water-Supply Options in Arsenic-Affected Regions in Cambodia: Targeting the Bottom Income Quintiles. Science of the Total Environment, 488-489, 521-531. http://dx.doi.org/10.1016/j.scitotenv.2013.12.011

[4] Doria, M.F. (2006) Bottled Water versus Tap Water: Understanding Consumers' Preferences. Water and Health, 4, 271-276.

[5] Saylor, A., Prokopy, L.S. and Amberg, S. (2011) What's Wrong with the Tap? Examining Perceptions of Tap Water and Bottled Water at Purdue University. Environmental Management, 48, 588-601. http://dx.doi.org/10.1007/s00267-011-9692-6

[6] Stoler, J., Fink, G., Weeks, J.R., Otoo, R.A., Ampofo, J.A. and Hill, A.G. (2012) When Urban Taps Run Dry: Sachet Water Consumption and Health Effects in Low Income Neighborhoods of Accra, Ghana. Health \& Place, 18, $250-262$. http://dx.doi.org/10.1016/j.healthplace.2011.09.020

[7] Hunter, P.R., MacDonald, A.M. and Carter, R.C. (2010) Water Supply and Health. PLoS Medicine, 7, e1000361. http://dx.doi.org/10.1371/journal.pmed.1000361

[8] Lee, Y. (2013) An Evaluation of Microbial and Chemical Contamination Sources Related to the Deterioration of Tap Water Quality in the Household Water Supply System. International Journal of Environmental Research and Public Health, 10, 4143-4160. http://dx.doi.org/10.3390/ijerph10094143

[9] Gruber, J.S., Ercumen, A. and Colford Jr, J.M. (2014) Coliform Bacteria as Indicators of Diarrheal Risk in Household Drinking Water: Systematic Review and Meta-Analysis. PLoS ONE, 9, e107429.

[10] Varol, M., Gökot, B., Bekleyen, A. and Şen, B. (2011) Water Quality Assessment and Apportionment of Pollution Sources of Tigris River (Turkey) Using Multivariate Statistical Techniques: A Case Study. River Research and Applications, 28, 1428-1438. http://dx.doi.org/10.1002/rra.1533

[11] Lapworth, D.J., Carter, R.C., Pedley, S. and MacDonald, A.M. (2015) Threats to Groundwater Supplies from Contamination in Sierra Leone, with Special Reference to Ebola Care Facilities. British Geological Survey, Nottingham.

[12] Ngugi, H.N., Home, P.G. and Mutwiwa, U.N. (2014) Impacts of Water and Sanitation Activities on the Environment in the Upper Mara Basin. Civil and Environmental Research, 6, 9-16.

[13] Srikanth, S. and Mohan, V.S. (2012) Influence of Terminal Electron Acceptor Availability to the Anodic Oxidation on the Electrogenic Activity of Microbial Fuel Cell (MFC). Bioresource Technology, 123, 480-487. http://dx.doi.org/10.1016/j.biortech.2012.07.049

[14] Rauen, W.B., Angeloudis, A. and Falconer, R.A. (2012) Appraisal of Chlorine Contact Tank Modeling Practices. Water Research, 46, 5834-5847. http://dx.doi.org/10.1016/j.watres.2012.08.013

[15] Achtenhagen, L., Melin, L. and Naldi, L. (2013) Dynamics of Business Models: Strategizing, Critical Capabilities and Activities for Sustained Value Creation. Long Range Planning, 46, 427-442.

http://dx.doi.org/10.1016/j.lrp.2013.04.002 